\title{
Influence of the Transport of Sea Spray on the Salinization of the Semiarid Region Waters (Bahia, Brazil)
}

\author{
Adriana M. Silva, ${ }^{a}$ Vânia P. Campos, ${ }^{*, b}$ Rafaela S. Domingues, ${ }^{b}$ Lícia P. S. Cruz ${ }^{b}$ and \\ Franciele O. Santana ${ }^{b}$ \\ ${ }^{a}$ Colegiado Acadêmico de Engenharia Agrícola e Ambiental, \\ Universidade Federal do Vale do São Francisco, 48902-300 Juazeiro-BA, Brazil \\ ${ }^{b}$ Departamento de Química Analítica, Instituto de Química, Universidade Federal da Bahia, \\ 40170-290 Salvador-BA, Brazil
}

\begin{abstract}
The sea spray can be transported to long distances, reaching the semiarid regions. In this work, the rainwater and the atmospheric particulate matter were characterized by investigating the presence of sea spray in the atmosphere of the semiarid region of Bahia, Brazil, aiming to study the influence of its transport on the salinization of the waters of the region. Stable isotopes of deuterium and oxygen-18 were also determined in the rain as environmental tracers, evaluating the isotopic ratios ${ }^{18} \mathrm{O} /{ }^{16} \mathrm{O}$ and $\mathrm{D} / \mathrm{H}$. The atmosphere of the region suffers marine influence, as well as resuspended soil particles and anthropogenic sources. The results demonstrate that the amount of sea spray which reaches the region is insufficient to interfere at the groundwater composition and the cause of its salinization should be attributed to the local geology and the evaporation and salt concentration process due to the high temperatures found in the region.
\end{abstract}

Keywords: sea spray, rainwater, particulate matter, stable isotopes, semiarid region

\section{Introduction}

The contribution of chemical species to the atmosphere represents an important mechanism of the hydrogeochemical processes, very significant in semiarid regions, that continuously suffers with a high frequency of dry periods. The problem of the salinization of surface waters in these regions certainly points to factors such as the recharging of water bodies with salinated water due to leaching of salts from the soil and to the salt concentration in the reservoirs because of the high evaporation rate typical in the Brazilian Northeast region. ${ }^{1}$

Atmospheric deposition is one of the main stages of the cycling and redistribution of the various chemical elements on the earth's surface. Therefore, their quantitative and qualitative knowledge is essentially important for the understanding of the biogeochemical cycles and anthropogenic influences on them. The wet deposition comprises the atmospheric particles and gases removal processes by the rain, fog or snow. The dry deposition

*e-mail: vaniaroc@ufba.br, vpalmeiracampos@gmail.com includes all the particles and gases transferring processes to all types of surfaces in the absence of moisture. ${ }^{2}$

The sea spray is a type of particulate matter produced naturally via the bubble-bursting process typically from whitecap generation. The bubbles scavenge organic matter as they rise to the surface. When they burst at the air-sea interface, they release a mixture of organic matter and inorganic sea salt, forming the sea spray aerosol, comprising the range of the submicrometre size and up to a few micrometres. ${ }^{3}$ It constitutes one of the most important natural aerosol systems and contributes to the Earth's radiative budget, biogeochemical cycling, impacts on ecosystems and even to regional air quality. ${ }^{4}$ Strongly dependent on the intensity of local winds, as shown Masiol et al., ${ }^{5}$ the sea spray can be transported to long distances and deposited in a wet and/or dry way and it can reach the semiarid regions, distant from its emission source. Being these particles composed basically of seawater $(\mathrm{NaCl}$ in carbonate/borate buffer), having thus an alkaline $\mathrm{pH}$, they are able to neutralize rain acidity by gas to particle interaction. ${ }^{6,7}$

The particulate phase of atmospheric aerosol is characterized by various physical parameters, with 
the distribution of its size as the most important one. Chemically, its composition reflects its emission sources; ${ }^{8}$ their size is an important parameter for the evaluation of their impact on the global climate system. ${ }^{9}$

The environmental isotopic ratios $\delta$ deuterium and $\delta$ oxygen- $18\left(\delta \mathrm{D}\right.$ and $\left.\delta \mathrm{O}^{18}\right)$ act as excellent natural tracers of air masses. They have been used very successfully as one of the unconventional tools in the study of the surface and underground water reserves. ${ }^{10}$ The natural isotopes appear in the water in low concentrations that vary when they undergo processes of changing phase, such as evaporation. Thus, the environmental tracers are used to identify and separate the different salinity sources, as well as the effect of evapotranspiration in these processes ${ }^{11}$ and it can be a useful tool in the study of the salinization processes, ${ }^{12}$ including salinization of the waters of the semiarid regions.

The processes of water and soil salinization, low rainfall rate and high evaporation rate of the water stored in reservoirs, contribute to the degradation of the quality of the water in the semiarid region of Brazil.

As a consequence of the vulnerability of water resources in semiarid areas, especially considering their scarcity, the study of the surface and underground water quality becomes important, aiming to provide water with better quality for more noble uses such as household supplies. There is a reasonable amount of data with results of analysis of legislated parameters in Brazil, which determine the quality of water in some parts of semiarid regions. ${ }^{1,13}$

Some studies indicate differentiated causes to the salinization of water, among them are the high evaporation rates, that concentrate the salts in the surface waters and in the soils during the dry periods; this salt is transported to the aquifer in the wet period by the recharge waters. ${ }^{14} \mathrm{Kovda}^{15}$ pointed as the main salinization source in the semiarid region, the aerosols coming from the marine atmosphere transported by the wind, which can be later leached from the soil and carried to the water bodies by runoff. On the other hand, according to Wetzel, ${ }^{16}$ the water conductivity values in tropical regions are related to the geochemical and climatic characteristics of the region.

In this work, rain water and atmospheric particulate matter were characterized, investigating the presence of sea spray in the Semiarid of Bahia, Brazil, intending to study the influence of its transport in the salinization of waters in the region. The $\delta \mathrm{D}$ and $\delta \mathrm{O}^{18}$ were also evaluated in the rain as environmental tracers. Additionally, there was a secondary data research on the geological characteristics of the semiarid region of the Bahia State, associated with the salinity of groundwater.

\section{Experimental}

\section{Sampling}

The Semiarid of Bahia occupies most of the northeastern Brazil and nearly $2 / 3$ of the state's territory. Among its main climatic characteristics, the high temperature average and extremely concentrated average annual rainfall of less than $800 \mathrm{~mm}$ stand out, creating long periods of drought (usually seven to nine months) and rainy periods restricted to few months of the year. ${ }^{17}$

For the proposed study, two areas in the Semiarid of Bahia (Figure 1) with different salinity characteristics of its natural waters were chosen: Juazeiro $\left(9^{\circ} 26^{\prime} 56^{\prime \prime} \mathrm{S}\right.$, $40^{\circ} 31^{\prime} 26^{\prime \prime} \mathrm{W}$ ), at $386 \mathrm{~m}$ of altitude, located in the north of the state, with groundwater that is often brackish, and
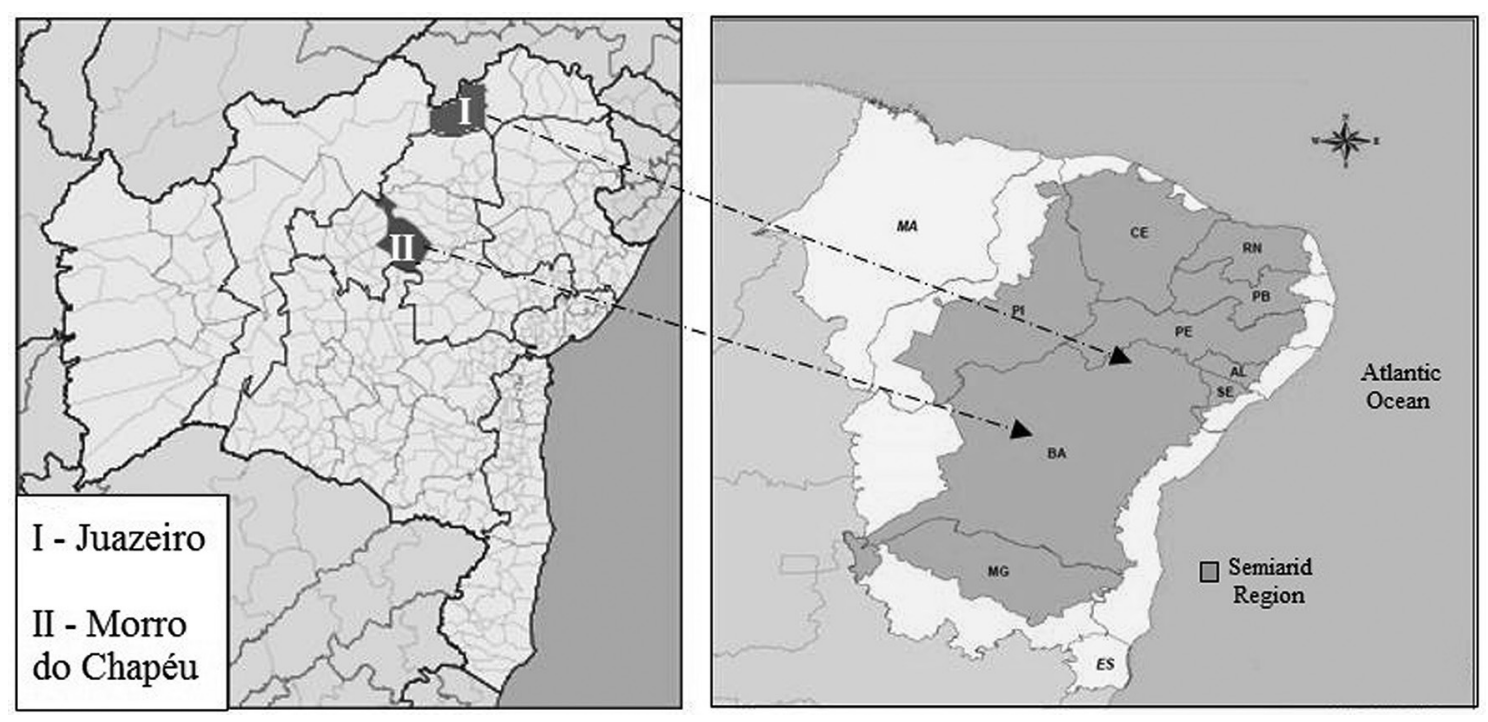

Figure 1. Location of the sampling stations: (a) on the map of Brazil; (b) on the map of the Brazilian semiarid region. 
it is characterized by the lack of rain and great irregularity in its distribution from 250 to $750 \mathrm{~mm}$ per year, low cloud cover, strong sunlight, high levels of evaporation, high average temperatures (ca. $27^{\circ} \mathrm{C}$ ) and low relative humidity; and Morro do Chapéu (11 $31^{\circ}$ ' $27^{\prime \prime}$ S, $41^{\circ} 08^{\prime} 08^{\prime \prime} \mathrm{W}$ ), at $1,003 \mathrm{~m}$ above sea level, located in the northwest of the state, a region with typically sweet groundwater.

All rainy events were sampled for periods of $24 \mathrm{~h}$ during one year, in both locations (55 rain samples from Juazeiro and 35 from Morro do Chapéu), for the determination of the major ions, using an automatic "wet only" deposition collector, set to about $1.5 \mathrm{~m}$ from the ground, consisting of a funnel $\left(598 \mathrm{~cm}^{2}\right)$ and a collector flask $(6 \mathrm{~L})$, both made of polyethylene, protected in a metal box.

Sampling and storaging rain water samples for determination of hydrogen and oxygen isotopes were made according to the instructions of the International Atomic Energy Agency (IAEA). ${ }^{18}$ The main problems that should be avoided are the fractionization by evaporation or diffusion of water vapor and/or isotopic exchange with the environment as well as with the storage bottle. Thus, a collector was mounted in a $20 \mathrm{~L}$ flask containing $100 \mathrm{~mL}$ of mineral oil to prevent evaporation and wrapped in aluminum foil to prevent sample degradation; there was a sieve on the top, disallowing the entry of other materials. Most rainy events that occurred during one year was collected. Immediately after sampling, aliquots of the samples were transferred in duplicate and stored in $100 \mathrm{~mL}$ amber glass bottles, fully completed and duly sealed, to avoid isotopic fractionation after collection. The samples were stored in a refrigerator and transported safely in thermal containers at low temperatures to the laboratory for measurement of stable isotopes.

The sampling of atmospheric particulate material was made in two intensive campaigns for 6 days, simultaneously, at the two sampling stations. The samplings were made for $24 \mathrm{~h}$ periods. The campaigns were scheduled for periods typically with predominant winds from the Atlantic and thus, based on the back trajectories study, it was observed that almost $100 \%$ of the sampling time of atmospheric particulate matter, the air masses arrived in both locations coming from the ocean.

Samples of suspended particles fractionated by size have been obtained with a Berner low-pressure impactor (BLPI) ${ }^{19}$ with six stages: $0.06,0.18,0.55,1.7,5.0$, and $>14.5 \mu \mathrm{m}$. The particles were sampled on a Nucleopore membrane $(47 \mathrm{~mm}$, $0.2 \mu \mathrm{m}$ ) at air flow of $19.2 \mathrm{~L} \mathrm{~min}^{-1}$ during $24 \mathrm{~h}$.

\section{Analyses and quality control}

The analytical methodology included ion chromatography for the determination of anions $\mathrm{Cl}, \mathrm{NO}_{3}{ }^{-}$and $\mathrm{SO}_{4}{ }^{2-}$, with limits of detection (LOD): 1.97, 0.322 and $1.25 \mu \mathrm{mol} \mathrm{L}^{-1}$, respectively, in the rainwater and particulate matter; molecular spectrophotometry using the indophenol method $(\lambda=630 \mathrm{~nm})$ for the determination of $\mathrm{NH}_{4}{ }^{+}$ (LOD: $0.0944 \mu \mathrm{mol} \mathrm{L}^{-1}$ ); flame photometry for $\mathrm{Na}^{+}$and $\mathrm{K}^{+}$(LOD: 2.61 and $0.246 \mu \mathrm{mol} \mathrm{L}^{-1}$, respectively); and atomic absorption spectrometry with flame for $\mathrm{Ca}^{2+}$ and $\mathrm{Mg}^{2+}$ (LOD: 1.70 and $0.251 \mu \mathrm{mol} \mathrm{L}{ }^{-1}$, respectively). The atmospheric particulate matter on the membranes was extracted with $1.5 \mathrm{~mL}$ of deionized water in ultrasound bath for $15 \mathrm{~min}$, followed by centrifugation and analysis, using the same above cited analytical methods. The LOD for $\mathrm{Cl}^{-}, \mathrm{NO}_{3}{ }^{-}, \mathrm{SO}_{4}{ }^{2-}$ and $\mathrm{Na}^{+}$in atmospheric particulate matter were: $0.107,0.0174,0.0678$ and $3.91 \mathrm{nmol} \mathrm{m}^{-3}$, respectively. Because it only had $1.5 \mathrm{~mL}$ of each sample of atmospheric particulate matter in different stages of the cascade impactor, it was not possible to analyze the other ions in this matrix. The $\mathrm{pH}$ measurements of the rain samples were made with a pHmeter MPA 210 (MLABOR) Model AF 405 (accuracy of $0.02 \mathrm{pH}$ units), using a combinated glass electrode, calibrated with buffer solutions. Conductivity measurements were made with a conductivimeter Marconi Model MACA 150, provided with a platinum cell with a constant of $1.0 \mathrm{~cm}^{-1}$, which allows thermostated measurements at $25 \pm 0.1^{\circ} \mathrm{C}$.

The isotopic analyzes were performed using Finnigan equipments: a mass spectrometer (MS, MAT Delta Plus), an automatic reactor (H Device, ThermoQuest) specific for analysis of the ratio $\mathrm{D} / \mathrm{H}$, and an online automatic sample preparation system (Gas Bench II) for the isotopic determination of the $\mathrm{O}^{18} / \mathrm{O}^{16}$ ratio. The standard water was a SMOW sample (standard mean ocean water), provided by the IAEA.

The quality control analysis was done using a standard reference rain, produced by the Canadian environmental agency (RAIN-97, lots 1107 and 407) containing all species determined in the rain and in the particulate matter. The quality of the data series was controlled by mass balance (total sum of cation equivalents versus ion equivalents) and comparing the calculated and measured conductivity values. ${ }^{20}$

\section{Statistical analysis}

The evaluation of possible correlations between the ions measured in the rain and in the atmospheric particulate matter was made using the Pearson correlation coefficient. ${ }^{21}$

With the use of principal component analysis (PCA), along with the hierarchical cluster analysis (HCA), the preview of the various ions in rainwater samples and particulate matter fractionated by size has become more rapid, objective and efficient. The program used 
for the application of this statistical tool was Statistica, version 10.0 .

\section{Air mass trajectories}

A study of the trajectories of air masses for the sampling period was done using the NOAA HYSPLIT model. ${ }^{22}$ The back trajectories were simulated for each period and sampling station, taking into accounts their respective altitudes and georeference, allowing the determination of the air masses trajectory that comes to each site.

Study of the geological characteristics of the water basins of the Semiarid of Bahia

Chemical secondary data on the groundwaters of the Bahia State were used. The major ions in groundwater were thus compiled, which could come from the sea spray. The data come from the registration of the wells, made available by the Company of Rural Engineering of Bahia (CERB) on the official website of the Geological Survey of Brazil ${ }^{23}$ through the Information System Groundwater (SIAGAS). Associations were made between the groundwater salinity of the region with the local geology, which will be discussed particularly in the two areas chosen for atmospheric studies of this work, that are part of the Salitre riverbasin, semiarid region of Bahia.

\section{Results and Discussion}

Inorganic characterization of the rain

In the two sampling sites (Juazeiro and Morro do Chapéu) the conductivity of the rain ranged from 21.5 to $70.8 \mu \mathrm{S} \mathrm{cm}^{-1}$ and 4.58 to $19.1 \mu \mathrm{S} \mathrm{cm} \mathrm{cm}^{-1}$, respectively. The molar concentrations and the percentage distribution

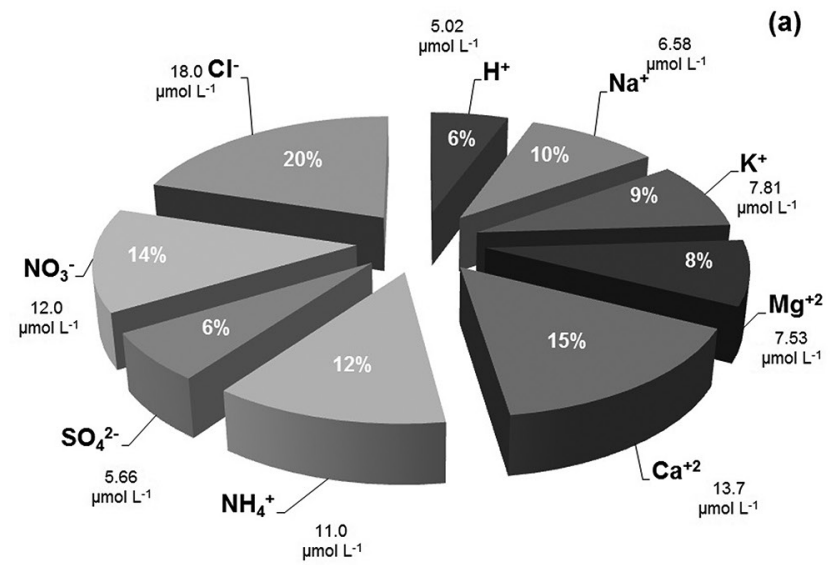

of the ionic species decreased in the following order: $\mathrm{Cl}^{-}>\mathrm{Ca}^{2+}>\mathrm{NO}_{3}{ }^{-}>\mathrm{NH}_{4}{ }^{+}>\mathrm{Na}^{+}>\mathrm{K}^{+}>\mathrm{Mg}^{2+}>\mathrm{SO}_{4}{ }^{2-}>\mathrm{H}^{+}$in Juazeiro (Figure 2a) and $\mathrm{Cl}^{-}>\mathrm{NH}_{4}{ }^{+}>\mathrm{Na}^{+}>\mathrm{NO}_{3}{ }^{-}>\mathrm{Mg}^{2+}>$ $\mathrm{H}^{+}>\mathrm{SO}_{4}{ }^{2-}>\mathrm{K}^{+}>\mathrm{Ca}^{2+}$ in Morro do Chapéu (Figure 2b). The presence of sea spray was detected by the ratio $\mathrm{Cl} / \mathrm{Na}^{+}$in the rainwater, which also shows other sources of $\mathrm{Cl}^{-}$in the atmosphere of the region, mainly in Juazeiro. As found by Gioda et al. ${ }^{24}$ in Puerto Rican rainforest, despite the altitude and distance from the sea, the atmosphere of the Semiarid of Bahia represented by wet precipitation, is strongly influenced by marine sources rather than local antropogenic sources. $\mathrm{NH}_{4}{ }^{+}$, one of the most abundant ions in the rain of the two localities, probably has its origin in the use of fertilizers in the vicinity of the rain sampling sites, which is more intense in Morro do Chapéu.

The results showed $\mathrm{pH}$ values of the rain in Juazeiro between 5.98 and 7.33, with 6.80 as volume-weighted mean (VWM); in Morro do Chapéu the $\mathrm{pH}$ values ranged from 6.40 to 7.24 , with 6.75 as VWM. These values suggest a neutralization of the rain acidity by ammonia either by basic soil particles or by sea spray. The calculated average parcel of the rain acidity neutralization by sea spray, using $\mathrm{Na}^{+}$as tracer, according to Campos et al., ${ }^{7}$ was 26.3 and $27.6 \%$, respectively, in those locations. ${ }^{7}$ The estimation of the influence of the sea spray in rain from Juazeiro and Morro do Chapéu showed, respectively, the following contribution of constituents: $\mathrm{Cl}^{-}, 56$ and $92 \% ; \mathrm{SO}_{4}{ }^{2-}, 38$ and $81 \% ; \mathrm{Mg}^{2+}, 14$ and 26\%; $\mathrm{Ca}^{2+}, 25$ and $57 \%$; and $\mathrm{K}^{+}, 2.2$ and $0 \%$. Thus, it is observed that in the locality of Morro do Chapéu, the contribution of marine aerosol is virtually the only source of chloride.

Inorganic characterization of the atmospheric particulate matter (PM)

Considering the two locations, the concentration level

Figure 2. Percentual distribution and volume-weighted mean ( $\left.\mu \mathrm{mol} \mathrm{L}^{-1}\right)$ of ions in the rain of the Semiarid of Bahia, Brazil: (a) Juazeiro; (b) Morro do Chapéu.

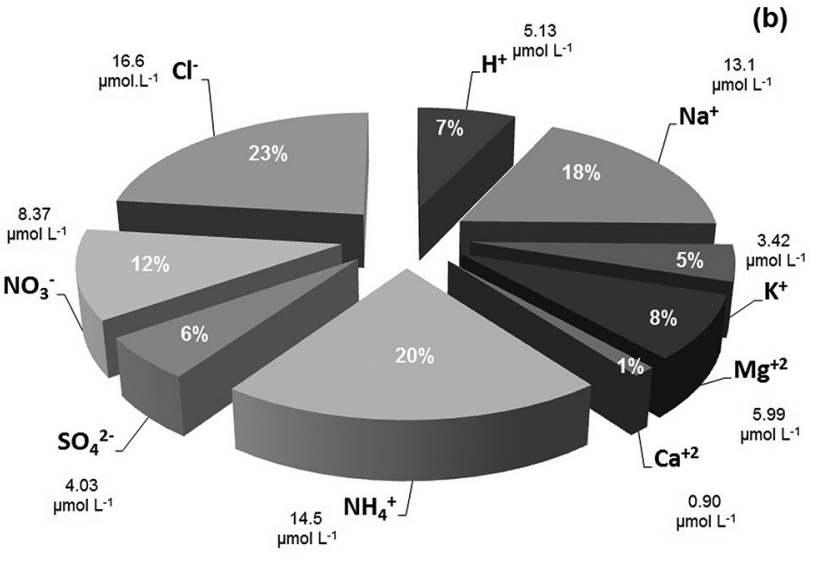



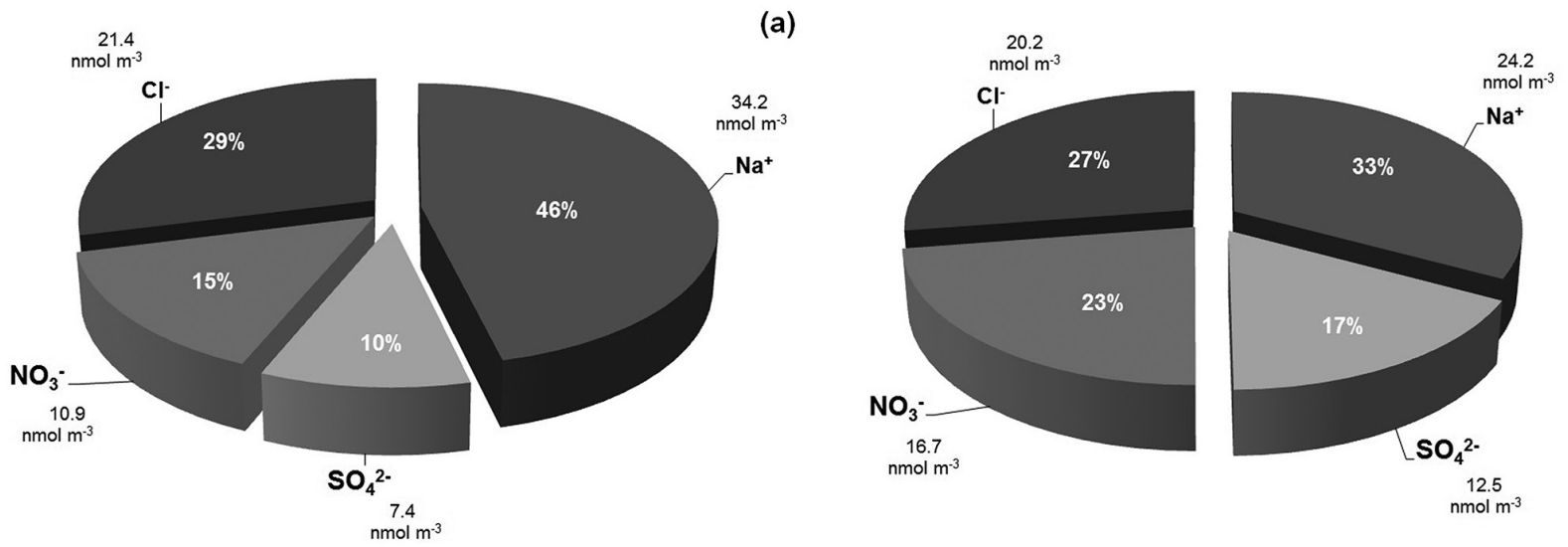

(b)

Figure 3. Percentual distribution and average concentration of the major ions in the atmospheric particulate matter of (a) Juazeiro; (b) Morro do Chapéu (Semiarid of Bahia, Brazil).

of the major inorganic species in PM was in the range of 13.6-26.9 nmol m${ }^{-3} \mathrm{Cl}^{-}, 3.23-6.17 \mathrm{nmol} \mathrm{m}^{-3} \mathrm{NO}_{3}^{-}$, 2.87-11.0 nmol m${ }^{-3} \mathrm{SO}_{4}{ }^{2-}$ and $11.5-37.0 \mathrm{nmol} \mathrm{m}{ }^{-3} \mathrm{Na}^{+}$. Figure 3 shows the average percentage distribution of these ions in the two locations, which characterizes the atmospheric particulate matter in that semiarid region. It can be seen in this figure that $\mathrm{Na}^{+}$and $\mathrm{Cl}^{-}$are the most abundant ions.

Figure 3 shows the distribution percentage and average concentration of the ions analyzed in the atmospheric particulate material. The apparent deficit in the chloride particle shown in this figure can be attributed to atmospheric reactions on the surface of sea spray, producing gaseous $\mathrm{HCl}^{25}$ This does not happen in the rain, as previously discussed with reference to other sources of $\mathrm{Cl}^{-}$in the region, which should be gas, since they are not represented in the particulate material.

The $\mathrm{SO}_{4}{ }^{2-}$ nss percentual (nss: non sea salt), comparing to total sulfate $\left(\mathrm{SO}_{4}{ }^{2-} \mathrm{T}\right)$ in the atmosphere of both locations, shows that the sea spray $\mathrm{SO}_{4}{ }_{4}^{2-}$ contribution to the particulate material is only 3 and $2 \%$, on average. Sievering et al. ${ }^{25}$ calculated the $\mathrm{SO}_{4}{ }^{2-}$ nss of the region as:

$$
\left[\mathrm{SO}_{4}{ }^{2-}\right]_{\mathrm{nss}}=\left[\mathrm{SO}_{4}{ }^{2-}\right]_{\mathrm{T}}-0.06\left[\mathrm{Na}^{+}\right]
$$

where $\left[\mathrm{SO}_{4}{ }^{2-}\right]_{\mathrm{T}}$ and $\left[\mathrm{Na}^{+}\right]$are concentrations of the ions in the particulate material; 0.06 is the molar ratio $\mathrm{SO}_{4}{ }^{2-} / \mathrm{Na}^{+}$ in the sea water.

Figure 4 shows the distribution by size of these particles, where $\mathrm{Na}^{+}$and $\mathrm{Cl}^{-}$can be observed predominantly as particles $>1.7 \mu \mathrm{m}$. This is observed also in other works. ${ }^{3,4,26}$ Since $\mathrm{Na}^{+}$and $\mathrm{Cl}^{-}$are mainly originated by sea spray, their particles are mainly distributed in the micrometric fraction. However, as expected for long-range transport, the sea spray content in the sub-micrometric fraction is not negligible, as can be seen in this figure.

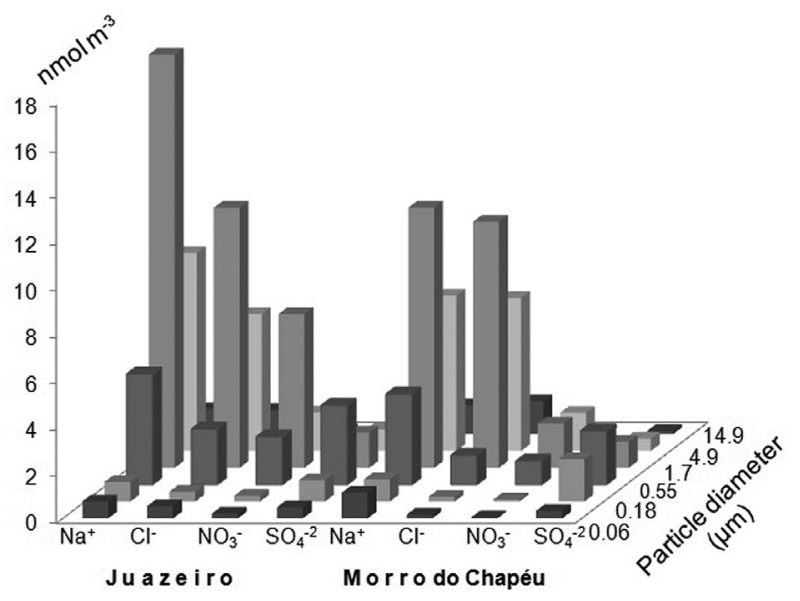

Figure 4. Average concentrations of $\mathrm{Cl}^{-}, \mathrm{Na}^{+}, \mathrm{SO}_{4}{ }^{2-}$ and $\mathrm{NO}_{3}{ }_{3}^{-}$fractionated by size in the atmospheric particulate material in the Semiarid of Bahia, Brazil (Juazeiro and Morro do Chapéu).

From Figure 4 the choride depletion seems to be high in both the stations, especially in the $0.55 \mu \mathrm{m}$ fraction measured at Morro do Chapéu. Figure 4 also shows that the predominance of $\mathrm{NO}_{3}{ }^{-}$and $\mathrm{SO}_{4}{ }^{2-}$ as atmospheric fine particles $(\leq 1.7 \mu \mathrm{m})$ suggests a secondary source by gas-particle or particle-particle convertion, according to Allen et al..$^{27}$ and Contini et al. ${ }^{28}$

\section{Isotopic characterization of the rain}

Stable isotopes of oxygen-18 and deuterium were determined in the rain as environmental tracers, evaluating the isotopic ratios ${ }^{18} \mathrm{O} /{ }^{16} \mathrm{O}$ and $\mathrm{D} / \mathrm{H}$, which can vary in the rain according to the water source and the processes that occur during their displacement and its surface storage, such as climate of the local of the precipitation (rainfall and temperature), geographical features (distance from the coast, elevation) and evaporation degree. The quantitation of the isotope ratio is given in terms of its deviation $(\delta \%$ ) 
in the sample compared to a standard water (standard mean ocean water, IAEA), $\mathrm{R}_{\mathrm{p}}$, and the sample isotopic ratio ${ }^{18} \mathrm{O} /{ }^{16} \mathrm{O}\left(\mathrm{R}_{\mathrm{a}}\right):{ }^{29}$

$\delta \%_{0}=\left[\left(\mathrm{R}_{\mathrm{a}}-\mathrm{R}_{\mathrm{p}}\right) / \mathrm{R}_{\mathrm{p}}\right] \times 10^{3}$

The deuterium excess (d) is a function of the source of the water vapor as well as of the hydrologic recycling degree in the basin. Increases in d result from the additional contribution of the recycled water vapor from the surface water evaporation and from the captured water by interception during the climatic event. ${ }^{30}$ According to Armengaud et al.,${ }^{31} \mathrm{~d}$ provides information on the distance of the evaporative sources, which originated the rains, i.e., air masses subject to several consecutive episodes of condensation and evaporation produces precipitations with elevated values of the deuterium excess.

The excess of deuterium (d) is expressed by equation 3 :

$\mathrm{d}=\delta \mathrm{D}-8 \delta \mathrm{O}^{18}(\% \circ)$

The parameter $d$ is also dependent on the location; the average value found by $\mathrm{Craig}^{29}$ was $10 \%$.

The data relating to the environmental isotopes oxygen-18 and deuterium in the precipitation characterized the studied area, with maximum and minimum values of 28.8 and $-58.5 \%$ or $\delta \mathrm{D}$ and 6.81 and $-2.55 \%$ o for $\delta \mathrm{O}^{18}$ in Juazeiro, and 23.3 and $-48.6 \%$ or $\delta \mathrm{D}$ and -0.02 and $9.49 \%$ o for $\delta \mathrm{O}^{18}$ in Morro do Chapéu, respectively. The amounts of deuterium excess corroborating with the type of precipitation of air masses that represent the precipitation of the region maximum and minimum values were: 41.5 and $-20.7 \%$ in Juazeiro, and 43.1 and $-1.1 \%$ in Morro do Chapéu, respectively. The more positive values found for Morro do Chapéu characterize waters from further afield. Figure 5 shows the daily variation of precipitation at this location as an example of the semiarid region of Bahia, with their isotopic ratios and the calculated deuterium excess, enabling the characterization of the temporal and spatial variability compared with the analysis of the origin of the deposited water in the region.

\section{Air mass characterization}

The study of the trajectories of air masses for each rain event and during the PM sampling period using the NOAA HYSPLIT mode ${ }^{21}$ showed that, in the most of the atmospheric PM sampling days, the air mass that arrived in the region passed over the ocean: frequency of $83 \%$ for Juazeiro and $75 \%$ for Morro do Chapéu. In the case of the

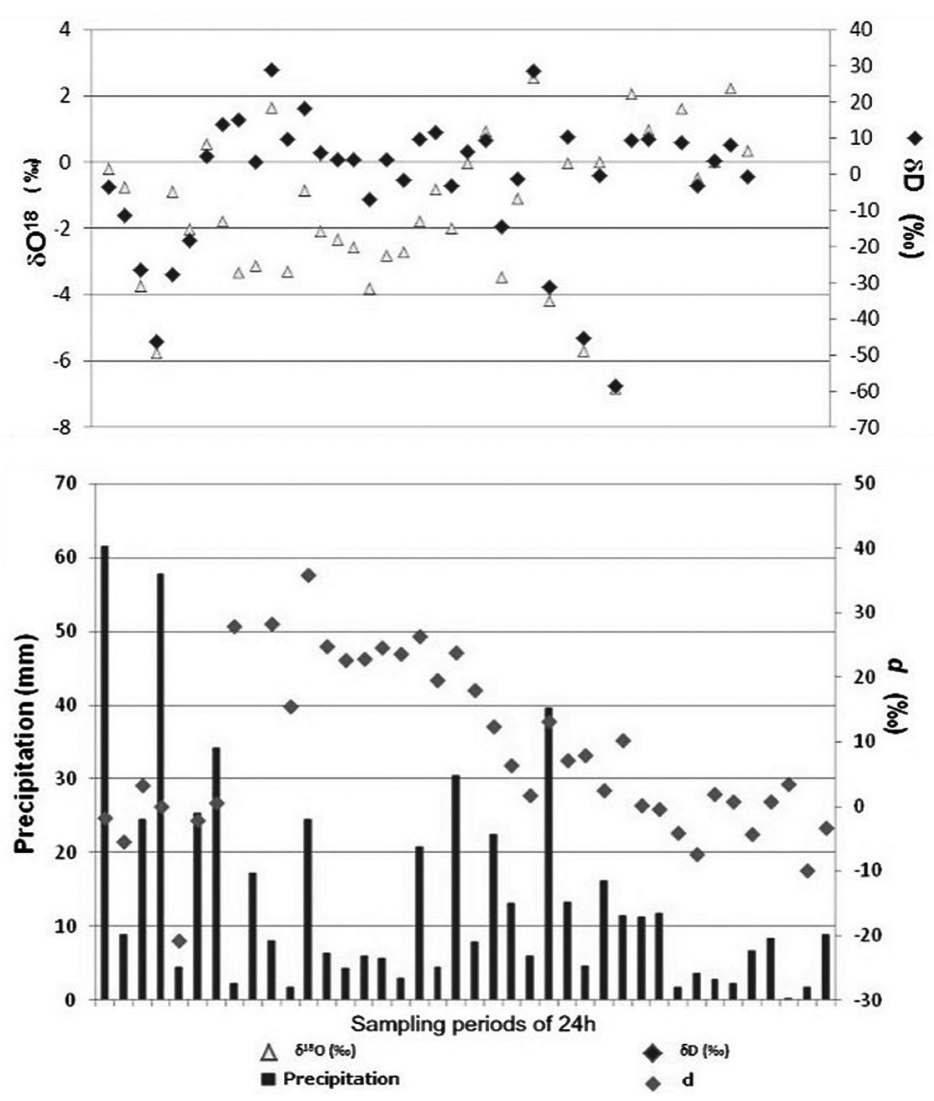

Figure 5. Change in the daily total precipitation and corresponding isotopic ratios and deuterium excess (Morro do Chapéu, Semiarid of Bahia, Brazil). 
sampled rainy events, the frequency of air masses coming from the ocean was relatively low for Juazeiro (29\%) and it was maintained at $75 \%$ for the locality Morro do Chapéu. It was possible to know because for each sampling day has been generated a backward trajectory graph, from the beginning of the $24 \mathrm{~h}$ of sampling until the end. Figure S1 (Supplementary Information) shows examples of backward trajectories of air masses of sampling days.

\section{Statistical analysis}

The hierarchical cluster analysis (HCA) was applied to the data arrays of the rainwater samples for both seasons (Juazeiro and Morro do Chapéu) using the Statistica 10.0 program, aiming to complement the studies conducted to investigate the marine influence and other sources (natural continental and anthropogenic) in the waters salinization in the Semiarid of Bahia. Analyzing the dendrograms obtained (Figure S2, Supplementary Information), one can see that for Juazeiro there is the division of five groups, showing strong similarities between (i) $\mathrm{Cl}^{-}$and $\mathrm{K}^{+}$, that could indicate common origin from biomass burning; (ii) $\mathrm{Na}^{+}$ and $\mathrm{pH}$; (iii) $\mathrm{NO}_{3}{ }^{-}$and $\mathrm{NH}_{4}^{+}$; (iv) $\mathrm{SO}_{4}{ }^{2-}, \mathrm{SO}_{4}{ }_{4}^{2-}$ nss $;(v) \mathrm{Ca}^{2+}$, $\mathrm{Mg}^{2+}$ and conductivity, which seems that, in this station, the crustal contribution is dominant with respect to sea spray. For Morro do Chapéu, there was the formation of three groups with great similarity: the first of them shows similarities between $\mathrm{Cl}^{-}, \mathrm{Na}^{+}$and $\mathrm{Mg}^{2+}$, indicating the sea spray contribution; the second group shows similarities between $\mathrm{SO}_{4}{ }^{2-}, \mathrm{SO}_{4}{ }^{2-}$ nss and $\mathrm{pH}$; the third group shows similarities between $\mathrm{NO}_{3}^{-}$, conductivity, $\mathrm{NH}_{4}^{+}, \mathrm{Ca}^{2+}$ and $\mathrm{K}^{+}$.

The correlation matrix (Table 1) constructed with the data of the rain samples of the region, showed the following strong positive correlations: (i) $\mathrm{Cl}, \mathrm{Na}^{+}$and $\mathrm{Mg}^{2+}$ displayed high positive correlation coefficient in Morro do Chapéu and high similarity according to the dendrogram, supporting the marine influence in this place; (ii) between nitrogen species $\left(\mathrm{NH}_{4}^{+}\right.$and $\left.\mathrm{NO}_{3}^{-}\right)$in both locations, related to human activities

Table 1. Correlation matrix with the data of the rain samples of the Juazeiro and Morro do Chapéu regions

\begin{tabular}{|c|c|c|c|c|c|c|c|c|c|c|c|c|}
\hline \multicolumn{13}{|c|}{ Juazeiro } \\
\hline & & 1 & 2 & 3 & 4 & 5 & 6 & 7 & 8 & 9 & 10 & 11 \\
\hline 1 & $\mathrm{Cl}^{-}$ & 1.0 & & & & & & & & & & \\
\hline 2 & $\mathrm{NO}_{3}^{-}$ & 0.36 & 1.0 & & & & & & & & & \\
\hline 3 & $\mathrm{SO}_{4}{ }^{2-}$ & $0.62^{\mathrm{a}}$ & $0.72^{\mathrm{a}}$ & 1.0 & & & & & & & & \\
\hline 4 & $\mathrm{SO}_{4}{ }^{2-}$ nss & $0.63^{\mathrm{a}}$ & $0.70^{\mathrm{a}}$ & $0.99^{b}$ & 1.0 & & & & & & & \\
\hline 5 & $\mathrm{NH}_{4}^{+}$ & 0.42 & $0.76^{a}$ & 0.58 & 0.59 & 1.0 & & & & & & \\
\hline 6 & $\mathrm{Ca}^{2+}$ & 0.53 & $0.65^{\mathrm{a}}$ & $0.93^{b}$ & $\mathbf{0 . 9 3}^{\mathrm{b}}$ & 0.51 & 1.0 & & & & & \\
\hline 7 & $\mathrm{Mg}^{2+}$ & 0.51 & $0.70^{\mathrm{a}}$ & $0.96^{\mathrm{b}}$ & $0.95^{b}$ & 0.50 & $0.95^{\mathrm{b}}$ & 1.0 & & & & \\
\hline 8 & $\mathrm{~K}^{+}$ & 0.58 & 0.44 & 0.57 & 0.59 & 0.29 & 0.48 & 0.53 & 1.0 & & & \\
\hline 9 & $\mathrm{Na}^{+}$ & 0.51 & $0.71^{\mathrm{a}}$ & $0.92^{\mathrm{b}}$ & $0.87^{b}$ & 0.48 & $0.84^{b}$ & $0.92^{\mathrm{b}}$ & 0.42 & 1.0 & & \\
\hline 10 & $\mathrm{pH}$ & -0.010 & -0.025 & 0.086 & 0.052 & -0.067 & 0.072 & 0.081 & 0.050 & 0.085 & 1.0 & \\
\hline 11 & Cond & 0.53 & $0.68^{\mathrm{a}}$ & $0.92^{\mathrm{b}}$ & $0.90^{b}$ & $0.60^{\mathrm{a}}$ & $0.92^{\mathrm{b}}$ & $0.91^{\mathrm{b}}$ & 0.51 & $0.86^{\mathrm{b}}$ & 0.12 & 1.0 \\
\hline \multicolumn{13}{|c|}{ Morro do Chapéu } \\
\hline & & 1 & 2 & 3 & 4 & 5 & 6 & 7 & 8 & 9 & 10 & 11 \\
\hline 1 & $\mathrm{Cl}^{-}$ & 1.0 & & & & & & & & & & \\
\hline 2 & $\mathrm{NO}_{3}^{-}$ & 0.41 & 1.0 & & & & & & & & & \\
\hline 3 & $\mathrm{SO}_{4}^{2-}$ & $0.67^{\mathrm{a}}$ & 0.30 & 1.0 & & & & & & & & \\
\hline 4 & $\mathrm{SO}_{4}^{2-}$ nss & 0.41 & 0.13 & 0.93 & 1.0 & & & & & & & \\
\hline 5 & $\mathrm{NH}_{4}^{+}$ & 0.30 & $0.65^{\mathrm{a}}$ & 0.24 & 0.09 & 1.0 & & & & & & \\
\hline 6 & $\mathrm{Ca}^{2+}$ & 0.20 & 0.44 & 0.050 & -0.090 & 0.46 & 1.0 & & & & & \\
\hline 7 & $\mathrm{Mg}^{2+}$ & $0.63^{\mathrm{a}}$ & 0.57 & 0.45 & 0.22 & 0.50 & $0.77^{\mathrm{a}}$ & 1.0 & & & & \\
\hline 8 & $\mathrm{~K}^{+}$ & 0.26 & 0.54 & 0.060 & -0.040 & 0.35 & 0.54 & 0.51 & 1.0 & & & \\
\hline 9 & $\mathrm{Na}^{+}$ & $0.88^{b}$ & 0.49 & 0.73 & 0.44 & 0.42 & 0.32 & $0.73^{\mathrm{a}}$ & 0.23 & 1.0 & & \\
\hline 10 & $\mathrm{pH}$ & -0.10 & -0.30 & 0.11 & 0.22 & -0.28 & 0.010 & 0.010 & -0.020 & 0.00 & 1.0 & \\
\hline 11 & Cond & 0.56 & $0.74^{\mathrm{a}}$ & 0.29 & 0.069 & 0.57 & $0.64^{\mathrm{a}}$ & $0.76^{\mathrm{a}}$ & 0.57 & $0.62^{\mathrm{a}}$ & -0.048 & 1.0 \\
\hline
\end{tabular}

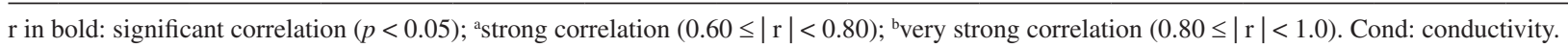


with emission of precursors: $\mathrm{NO}_{\mathrm{x}}\left(\mathrm{NO}+\mathrm{NO}_{2}\right)$, by more intense emissions from biomass burning, $\mathrm{NO}_{3}^{-}$ion being the major oxidation products of these compounds; $\mathrm{NH}_{4}{ }^{+}$, by management of animal waste, disposal of sewage, landfills and dumps; (iii) $\mathrm{SO}_{4}{ }^{2-}$ and $\mathrm{SO}_{4}{ }^{2-}$ nss correlates with $\mathrm{NO}_{3}{ }^{-}$in the rain of Juazeiro, showing common origin of these species with ions derived from soil resuspension, such as $\mathrm{Mg}^{2+}$ and $\mathrm{Ca}^{2+}$. Therefore, in this station, the main source of $\mathrm{SO}_{4}{ }_{4}^{2-}$ nss could be the continental dust. On the other hand, in Morro do Chapéu, the low correlation coefficient between $\mathrm{SO}_{4}{ }_{4}^{2-}$ nss and $\mathrm{NO}_{3}{ }^{-}$and also the dissimilarity shown in the dendrogram indicate no common origin and also corroborates with the low percentual (19\%) of anthropogenic contribution found to $\mathrm{SO}_{4}{ }^{2-}$ in this location rain.

The principal component analysis technique (PCA) was applied to the data of atmospheric particulate matter in the two sampling locations used in this study. Samples were identified by a code that identifies the station (J: Juazeiro; M: Morro do Chapéu), the month of the collection (A: April; N: November), the initial date of sampling and identification of the particles (F: fine particles; $\mathrm{C}$ : coarse particles).

Figure S3 (Supplementary Information) shows the graphs of scores and loadings using two main components to explain the results that are associated with each variable $\left(\mathrm{Cl}-\mathrm{NO}_{3}{ }^{-}, \mathrm{SO}_{4}{ }^{2-}, \mathrm{Na}^{+}\right)$for fine and coarse particles. Looking at this figure, the PCA showed that the first and second main components explain 81 and 14\%, respectively, of the total variance.

The ions $\mathrm{Na}^{+}$and $\mathrm{Cl}^{-}$were the most abundant in the coarse fraction of the particles, suggesting a significant contribution by the sea spray in this size range of the particulate matter that comes to this region, especially in Morro do Chapéu.
The predominance of $\mathrm{SO}_{4}{ }^{2-}$ in fine mode in both sampling stations, after a long period of drought, confirms its secondary source by particle-particle or gas-particle conversion through the $\mathrm{SO}_{2}$ oxidation, emitted from burning local biomass. The main contribution of the ion $\mathrm{NO}_{3}{ }^{-}$in fine particulate material supports the existence of gas phase reactions between $\mathrm{NH}_{3}, \mathrm{Cl}^{-}$from sea spray and nitric acid, with the formation of $\mathrm{NH}_{4} \mathrm{Cl}$ and $\mathrm{NH}_{4} \mathrm{NO}_{3}$, partially explaining the loss of chloride of the coarse particulate and, at the same time, nitrate gain for the fine particulate.

\section{Contribution of sea spray to the groundwater of the study area}

Table 2 presents the ranges of total concentration of the main ions in groundwater, which could originate from the sea spray, as well as nss (non sea salt) concentrations and the contribution of sea spray (ss) to those sampled waters from six wells in the region of Juazeiro and eight wells in the region of Morro do Chapéu.

The estimation of the sea spray in the groundwater from Juazeiro and Morro do Chapéu showed, respectively, the following maximal contribution of constituents (Table 2): 4.4 and $26 \% \mathrm{Cl}^{-} ; 38$ and $11 \% \mathrm{SO}_{4}^{2-;} ; 1.4$ and $17 \% \mathrm{Ca}^{2+}$; 5.5 and $26 \% \mathrm{Mg}^{2+}$; and 24 and $0.0 \% \mathrm{~K}^{+}$. These data show that the amount of sea spray that reaches the region is not sufficient to salinize the groundwaters.

The municipalities of Juazeiro and Morro do Chapéu, areas considered to the atmospheric study in this work, are located in the Salitre river basin in semiarid region of Bahia. The research that was done in this work on the geological characteristics of these locations showed that this basin is under different hydrogeologic domains, which are entities resulting from the grouping of geologic units

Table 2. Ranges of total concentration, nss (non sea salt) and sea spray contribution in the groundwater of the studied areas. Water basin of the Salitre river, Semiarid of Bahia, Brazil

\begin{tabular}{|c|c|c|c|c|c|c|}
\hline \multirow[b]{2}{*}{ Ion } & \multicolumn{3}{|c|}{ Juazeiro } & \multicolumn{3}{|c|}{ Morro do Chapéu } \\
\hline & $\mathrm{C}_{\mathrm{T}} /\left(\mu \mathrm{mol} \mathrm{L} \mathrm{L}^{-1}\right)$ & $\begin{array}{c}\mathrm{C}_{\mathrm{nss}} /\left(\mu \mathrm{mol} \mathrm{L} \mathrm{L}^{-1}\right) \\
(\%)\end{array}$ & Sea spray / \% & $\mathrm{C}_{\mathrm{T}} /\left(\mu \mathrm{mol} \mathrm{L} \mathrm{L}^{-1}\right)$ & $\begin{array}{c}\mathrm{C}_{\mathrm{nss}} /\left(\mu \mathrm{mol} \mathrm{L} \mathrm{L}^{-1}\right) \\
(\%)\end{array}$ & Sea spray / \% \\
\hline $\mathrm{Na}^{+}$ & $0.261-304$ & - & - & $632-50870$ & - & - \\
\hline $\mathrm{Cl}^{-}$ & $253-406$ & $\begin{array}{c}253-388 \\
(95.6-100)\end{array}$ & $0.0-4.4$ & $1022-147242$ & $\begin{array}{c}761-143990 \\
(74.5-98)\end{array}$ & $2.0-26$ \\
\hline $\mathrm{SO}_{4}^{2-}$ & $47.6-70.8$ & $\begin{array}{c}29.4-70.8 \\
(61.7-100)\end{array}$ & $0.0-38$ & 829-18229 & $\begin{array}{l}829-17624 \\
(88.6-100)\end{array}$ & $0.0-11$ \\
\hline $\mathrm{Ca}^{2+}$ & $151-1290$ & $\begin{array}{c}151-1274 \\
(98.6-100)\end{array}$ & $0.0-1.4$ & $1518-56000$ & $\begin{array}{c}1257-52918 \\
(82.8-98)\end{array}$ & $2.0-17$ \\
\hline $\mathrm{Mg}^{2+}$ & $89.7-326$ & $\begin{array}{c}89.7-308 \\
(94.5-100)\end{array}$ & $0.0-5.5$ & $984-33210$ & $\begin{array}{c}723-30158 \\
(73.5-92)\end{array}$ & $8.0-26$ \\
\hline $\mathrm{K}^{+}$ & $25.6-76.9$ & $\begin{array}{c}25.6-58.7 \\
(76.3-100)\end{array}$ & $0.0-24$ & $51.3-659$ & $\begin{array}{c}51.3-659 \\
(100)\end{array}$ & 0.0 \\
\hline
\end{tabular}




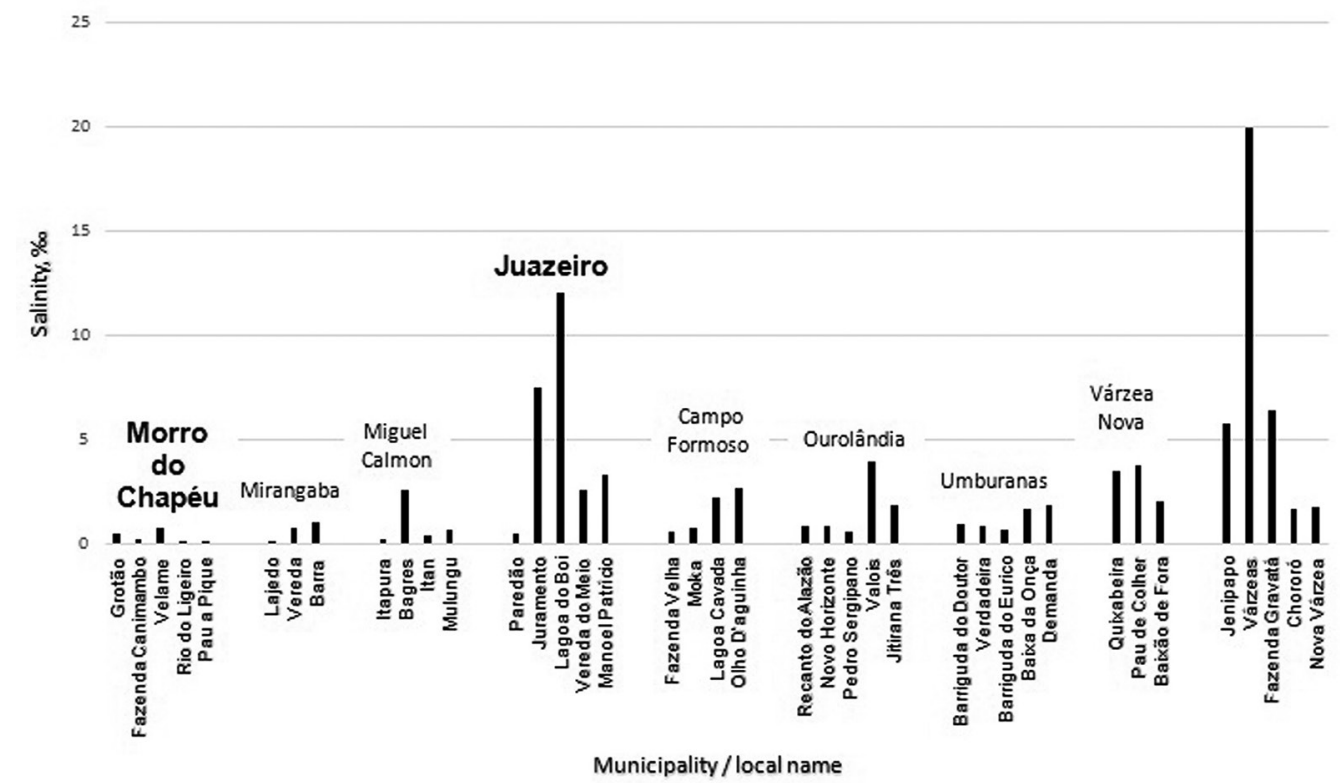

Figure 6. Salinity levels of groundwater in different municipalities/locations of the Salitre river basin in the Semiarid of Bahia, Brazil, highlighting the municipalities of Morro do Chapéu and Juazeiro.

with hydrogeologic affinity, having the basis mainly the lithologic characteristics of the rocks. ${ }^{32}$ These domains, in the case of the semiarid region of the Bahia State and its relation to the increasing salinity of the groundwater are: the coverage domain (freshwater), domain of the sediment and metasediments (freshwater and slightly brackish water), domain of the limestones (brackish water) and domain of the crystalline (very brackish water). The municipality of Morro do Chapéu prevails largely in the metasediments domain, with freshwater, with a small part in the domain of the limestones, and few points with slightly brackish water, represented in Figure 6 by the locality of Velame $(0.72 \%$ o).

The municipality of Juazeiro, which also belongs to the domain of metasediments, in a small part, has waters with low salinity, for example in the locality of Paredão $(0.41 \%$, Figure 6); it predominates in the limestones domain, imprinting a strong salinization of its groundwater (2.3 to $12 \%$, Figure 6 ), with the salinity varying according to local rainfall and reflecting the mineralogical composition of the rock. Figure 6 shows the salinity of the water in these and other cities of the Salitre river basin, highlighting the municipalities of Morro do Chapéu and Juazeiro.

\section{Conclusions}

The composition of rainwater in the two sampling stations, Juazeiro and Morro do Chapéu, in the Semiarid of Bahia, Brazil, showed that the atmosphere of both localities suffer marine influence, as well as resuspended soil particles and anthropogenic sources. The results demonstrate the potential of certain isotopic tracers in the rain, for the understanding of the hydrological cycle in the two localities in the semiarid region in the studied area: in Morro do Chapéu, precipitation waters are mostly coming from further afield sites, while in Juazeiro, they come from the region, although air masses often reach the coast, as shown by backward trajectories. The estimate of the contribution of sea spray in the rain in Juazeiro is much less (56\%) than in Morro do Chapéu (92\%), although the groundwater is sweet in this locality. The contribution of the sea spray for the groundwater at the study areas calculated using $\mathrm{Na}^{+}$as tracer showed to be small in relation to the main ions that could have this origin: $\mathrm{Cl}-\mathrm{SO}_{4}{ }^{2-}, \mathrm{Ca}^{2+}, \mathrm{Mg}^{2+}$ and $\mathrm{K}^{+}$. This allows to conclude that the amount of sea spray which reaches the region is insufficient to interfere at the groundwater composition. As showed by the study, the salinity of the groundwater is associated with the geological characteristics of these locations. Thus, the cause of the salinization of the waters in the Semiarid of Bahia, Brazil, must be attributed to the local geology and processes of evaporation and concentration of salts, due to the high temperatures to which the region is subjected.

\section{Supplementary Information}

Supplementary data are available free of charge at http://jbcs.sbq.org.br as PDF file.

\section{Acknowledgments}

The authors acknowledge UNIVASF (Federal University of São Francisco Valley, Juazeiro-BA, Brazil); CAPES 
(Coordination for the Improvement of Higher Education Personnel) and Prof Dr Maria Zucchi from the Institute of Physics, Federal University of Bahia.

\section{References}

1. Brito, L. T. L.; Srinivasan, V. S.; Silva, A. S.; Gheyi, H. R.; Galvão, C. O.; Hermes, L. C.; Rev. Bras. Eng. Agríc. Ambient. 2005, 9, 596.

2. Finlayson-Pitts, B. J.; Pitts, J. N.; Chemistry of the Upper and Lower Atmosphere: Theory, Experiments and Applications; Academic Press: San Diego, USA, 2000.

3. Quinn, P. K.; Collins, D. B.; Grassian, V. H.; Prather, K. A.; Bates, T. S.; Chem. Rev. 2015, 115, 4383.

4. O’Dowd, C. D.; De Leeuw, G.; Philos. Trans. R. Soc., A 2007, $365,1753$.

5. Masiol, M.; Squizzato, S.; Ceccato, D.; Rampazzo, G.; Pavoni, B.; Atmos. Environ. 2012, 63, 117.

6. Bruynseels, F.; Storms, H.; Tavares, T. M.; Van Grieken, R.; J. Environ. Anal. Chem. 1985, 23, 1.

7. Campos, V. P.; Costa, A. C. A.; Tavares, T. M.; J. Environ. Manage. 2007, 84, 204.

8. Seinfeld, J. H.; Pandis, S. N.; Atmospheric Chemistry and Physics: From Air Pollution to Climate Change; John Wiley and Sons: New York, USA, 1998.

9. Vignati, E.; Facchini, M. C.; Rinaldi, M.; Scannell, C.; Ceburnis, D.; Sciare, J.; Kanakidou, M.; Myriokefalitakis, S.; Dentener, F.; O’Dowd, C. D.; Atmos. Environ. 2010, 44, 670.

10. Shamsi, A.; Kasemi, G. A.; J. Geope. 2014, 4, 73. DOI: 10.22059/jgeope.2014.51193.

11. Clark, I.; Fritz, P.; Enviromental Isotopes in Hydrogeology, $2^{\text {nd }}$ ed.; Lewis Publishers: New York, USA, 1997.

12. Ghosh, P.; Chakrabarti, R.; Bhattacharya, S. K.; Chem. Geol. 2013, 335, 118.

13. Oliveira, C. N.; Campos, V. P.; Medeiros, Y. D. P.; Quim. Nova 2010, 33, 1059.

14. Whipkey, C. E.; Capo, R. C.; Chadwick, O. A.; Stewart, B. W.; Chem. Geol. 2000, 168, 37

15. Kovda, D. A.; Irrigation, Drainage and Salinity: An International Sourcebook; FAO/UNESCO: Paris, France, 1973.
16. Wetzel, R. G.; Limnology - Lake and River Ecosystems, $3^{\text {rd }}$ ed.; Elsevier Academic Press: California, USA, 2001.

17. Giulietti, A. M.; de Queiroz, L. P. In Towards Greater Knowledge of the Brazilian Semi-Arid Biodiversity; de Queiroz, L. P.; Rapini, A.; Giulietti, A. M., eds.; Ministério da Ciência e Tecnologia (MCT): Brasília, Brazil, 2006.

18. http://www.iup.uni-heidelberg.de/institut/studium/lehre/ AquaPhys/docPAS/IEHC_Vol3.pdf, accessed in May 2017.

19. Wang, H.-C.; John, W.; Aerosol Sci. Technol. 1988, 8, 157.

20. World Meteorological Organization (WMO); Manual for the GAW Precipitation Chemistry Programme, No. 160; GAW Precipitation Chemistry Science Advisory Group: New York, USA, 2004.

21. Callegari, J.; Sidia, M.; Bioestatística: Princípios e Aplicações; Artemed: Porto Alegre, Brazil, 2003.

22. http://ready.arl.noaa.gov/HYSPLIT.php, accessed in May 2017.

23. http://siagasweb.cprm.gov.br/layout, accessed in May 2017.

24. Gioda, A.; Mayol-Bracero, O. L.; Scatena, F. N.; Weathers, K. C.; Mateus, V. L.; McDowell, W. H.; Atmos. Environ. 2013, 68, 208.

25. Sievering, H.; Ennis, G.; Gorman, E.; Global Biogeochem. Cycles 1990, 4, 395.

26. Andreas, E. L.; Edson, J. B.; Monahan, E. C.; Rouault, M. P.; Smith, S. D.; Boundary-Layer Meteorol. 1995, 72, 3.

27. Allen, H. M.; Draper, D. C.; Ayres, B. R.; Ault, A.; Bondy, A.; Takaham, S.; Modini, R. L.; Baumann, K.; Edgerton, E.; Knote, C.; Laskin, A.; Wang, B.; Fry, J. L.; Atmos. Chem. Phys. 2015, $15,10669$.

28. Contini, D.; Cesari, D.; Genga, A.; Siciliano, M.; Ielpo, P.; Guascito, M. R.; Conte, M.; Sci. Total Environ. 2014, 472, 248.

29. Craig, H.; Science 1961, 133, 1702.

30. Rozanski, K.; Araguás-Araguás, L.; Gonfiantini, R.; Geophys. Monogr. Ser. 1993, 78, 1.

31. Armengaud, A.; Kroster, R.; Jouzel, J.; Ciais, P.; Geophys. Res. 1998, 103, 8947.

32. Bomfim, L. F. C.; Jesus, J. D. A.; Mapa de Domínios/ Subdominios Hidrogeológicos da Bahia; CPRM: Salvador, BA, Brazil, 2004. 